\title{
一般口演 12
}

\section{液体へのとろみづけが舌運動と舌圧発現様相に及ぼす影響}

The effect of thickner on tongue motion and pressure production against hard palate

○兒玉匠平, 藤原茂弘, 設樂仁子, 大川純平, 堀一浩, 小野高裕

Kodama S, Fujiwara S, Shitara S, Okawa J, Hori K, Ono T

新潟大学大学院医歯学総合研究科包括歯科補綴学分野

Division of Comprehensive Prosthodontics Niigata University Graduate School of Medical and Dental Sciences

\section{I . 目的}

舌は緻密でダイナミックな動きをすることで様々な機 能を生み出し, 咀嚼・嚥下・構音に扮いて重要な役割を 担っているが，口腔内にあるため直接運動する様子を観 察することはできない.

我々は舌運動モーションキャプチャシステム（電磁 アーティキュログラフ, 以下 EMA とする) と舌圧測定 の同時測定により，嚥下口腔期のバイオメカニクスを定 量的に解析するためのシステムを構築し, 水嚥下時の舌 運動と舌圧発現様相の特徴㧍よび双方の関係性について 第59回学術大会で報告した。

摂食嚥下リハビリテーションの臨床において, 誤嚥の リスクの高い嚥下障害患者に対して液体のとろみ付けが しばしば行われているが，とろみ水を讌下した際の舌運 動と舌圧について，それぞれ単独での計測は行なわれて いるものの同時測定はこれまで行われていない.

そこで今回我々は，本システムを用いて液体へのとろ み付けが，舌運動と舌圧発現に及ぼす影響について解析 を試みた。

\section{II. 方 法}

\section{1. 被験者}

健常若年男性 8 名（平均年齢 $30.0 \pm 3.3$ 歳）

\section{2. 実験器具・被験試料}

舌運動測定には EMA（AG-501，カールステン社), 舌圧測定には 5 カ所の感圧点を有する舌圧センサシート と Swallow Scan System（ニッタ社）を用いた。 まず口蓋に舌圧センサシートを貼付し，歯科適合試験
用材料（デンスポット，昭和薬品化工社）を舌圧センサ シートの口蓋正中前方部，後方部に位置するChs.1,3に 塗布した後, 唾液嚥下を行わせ，舌上にこれら感圧点と 接触する部位を印記させた。その部位から右側に $5 \mathrm{~mm}$ 離れた部位を EMAの標点であるコイルの貼付位置と し，前方を Ant，後方をPost とした（図 1). 被駼試料 は $3 \mathrm{ml}$ の水ととろみ調整郕（つるりんこ Quickly，クリ ニコ社）を用いてケチャップ状に調整したとろみ水とし た.

\section{3. 計測方法}

被験者の舌背もしくは口腔底に被験試料を注入し保持

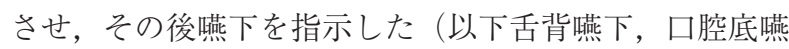
下とする ${ }^{1)}$. コイルを貼付した状態に馴化させるため, 2 回ずつ練習を行わせた後, それぞれ 7 回ずつ計測し た。

\section{4. 解析方法}

得られた EMA の舌運動軌跡から上下運動成分を抽出 し，変化点を時間軸上にプロットし(1)〜 (7)のタイムポイ ントを設定した（図 2 )。水與菲下時ととろみ嚥下時にお ける各タイムポイント間の時間の比較および各 Ch. の舌 圧最大值, 舌圧持続時間の比較を Wilcoxon の符号付順 位検定を用いて行った。

また，舌運動のタイムポイントと舌圧波形上の Onset および Offsetとのタイミングの同期性について, 級内 相関係数を用いて比較を行った，有意水準はすべて $5 \%$ とした。

\section{III. 結果及び考察}

水ととろみ水で鱟下時舌運動はほぼ共通のパターンを 


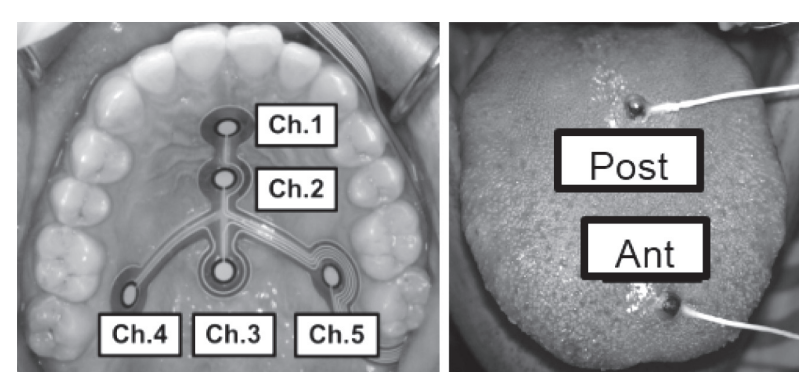

図 1 測定波形一例とセンサ貼付位置 (左：舌圧センサシート 右：EMAのコイル)

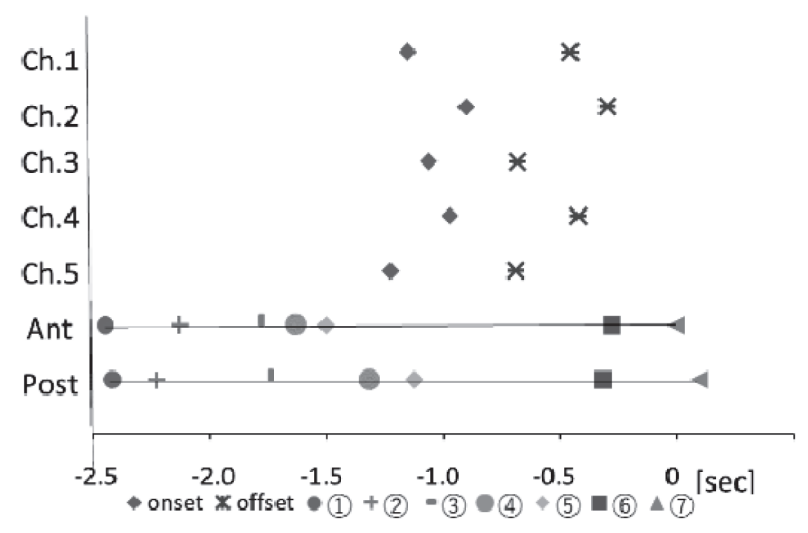

図 3 舌圧発現と舌運動のタイムポイント

示し，舌背臙下および口腔底讌下ともに口蓋に接触する 前に一度停止する動作が見られた。しかし, 舌背嚥下と 比較して口腔底燕下は運動のパターンが安定していたた め, 口腔底嚥下で観察された運動の変化点をタイムポイ ント(1)〜 (7)として設定し（図 2), 舌運動, 舌圧の時間 的要素の解析を行った。

舌運動の各夕イムポイントと舌圧発現の時間的関連を

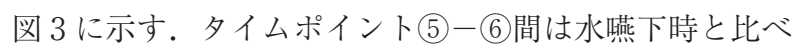

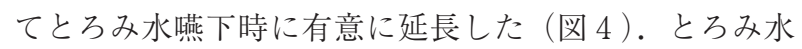
嚥下時の舌圧持続時間は水嚥下時と比べて有意に延長し ており，この結果と合致する。

舌前方と舌後方の運動のタイミングを比較するとタイ ムポイント(4)，(5には前後で発現に時間差が認められ， 舌前方が先行して動き, 舌後方が遅れて動いていた。 こ のような時間的ずれは液体を咽頭へ送り込む動作を表し ていると考えられた。一方, 夕イムポイント(4), (5)それ ぞれの Ant-Post 間の時間差は, とろみ水と比較して水 鱟下時の方が延長する傾向を認め, 特に(4)で有意に延長

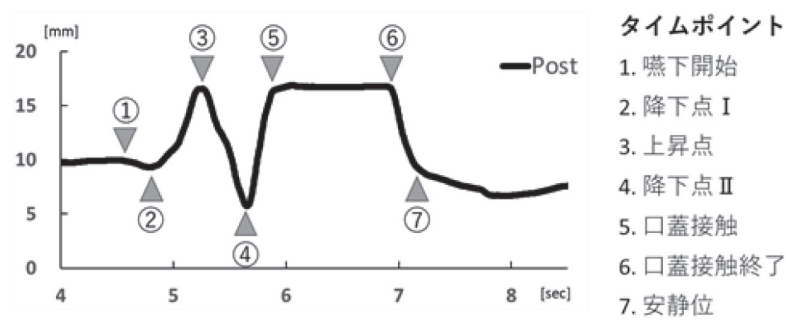

図 2 舌上下運動成分記録の一例とタイムポイント
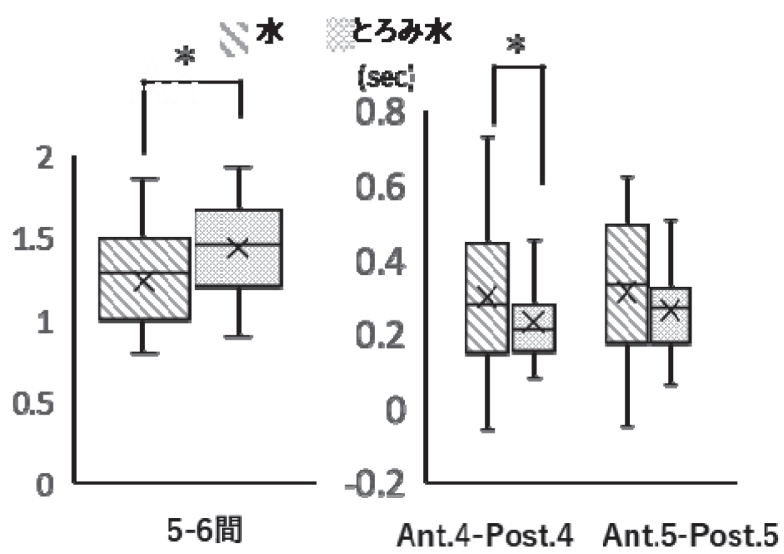

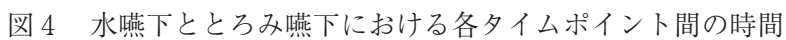
の比較

していた（図 4)。このことからとろみ水の鱟下におい ては舌前方と後方が口蓋に接触する際の時間差を少なく して鱟下を行っていることが示された。

また, 舌圧の各感圧点の Onsetとタイムポイント (5) との間には高い級内相関係数を認め, 舌の運動と舌圧発 現には時系列上の同期性があることが示唆された。

以上より, 液体のとろみ付けが舌運動と舌圧発現様相 に与える影響について，双方の同時計測を行うことでよ り詳細に評価することができた。今後は接触前の舌運動 の速さや移動距離などの運動量的な要素についても，よ り詳細な分析を行っていく予定である。

\section{N. 文献}

1) WJ Dodds, AJ Taylor, ET Stewart, MK Kern et al: Tipper and dipper types of oral swallows. American Journal of Roentgenology, 153: 1197-1199, 1989 